\title{
USABILITY MEASUREMENT OF GOOGLE CLASSROOM APPLICATIONS AS E- LEARNING FOR STUDENTS OF DEPARTMENT OF BUILDING ENGINEERING EDUCATION IKIP GUNUNG SITOLI
}

\author{
${ }^{1}$ Envilwan Berkat Harefa \\ ${ }^{1}$ Department of Building Engineering Education IKIP Gunung Sitoli \\ envilwanharefa@gmail.com
}

Accepted: September $5^{\text {th }}, 2020$. Published: October $6^{\text {th }}, 2020$

\begin{abstract}
This study aims to determine the level of usefulness of the Google Classroom application by distributing questionnaires to respondents. This research was a case study research. The results of the questionnaire were measured using a Likert scale. Google classroom was an open source application from Google that can be used for learning systems or can be called elearning. This application is a new application and still a few are using it in the learning system in schools and colleges. From the measurement results it will be known the level of usability value of the google classroom application which was used as e-learning for students in the IKIP Gunungsitoli Building Engineering Education study program.
\end{abstract}

Keywords: Google classroom, usability, Likert scale. 


\section{Introduction}

Learning is a process, way, act of making people or living things learn. The previous definition stated that a human being can see in the changes that occur, but not learning itself. The concept is theoretical, and thus not directly observable.

In today's digital era, most of the human needs are met by online systems. There are so many applications that are made to simplify work and human needs, as well as in the world of education. Many online applications are used in the world of education, for example school and campus websites, academic information systems, and others.

This research is motivated by the implementation of lectures for students and also the learning process for students which is carried out online / online. This is caused by the Corona virus pandemic which is hitting the world, including Indonesia. Through the Minister of Education giving instructions that all learning activities must be carried out online / online to stop the spread of the corona virus.

In carrying out the intended learning process, students / learners are required to be able to master technology that can help them in learning online. One of the technologies that is widely used by Lecturers / Teachers is Google Classroom.

This application is a free service from Google that can be used in the learning system as e-learning. This application includes applications especially in the Department of Building Engineering Education of IKIP Gunungsitoli. In this study program, they started using the Google Classroom application service as e-learning. To find out the level of usability using this application, we will measure the level of usability by using the questions in the questionnaire, while to find the value, a Likert scale is used on a scale of 1 to 4 . Google classroom is considered to be one of the best platforms to improve Lecturers' workflow. This application provides a powerful feature set which makes it an ideal tool.

\section{Research Method}

Population relates to all groups of people, events, or objects that are the center of research attention for research. The sample is a part of the population. This includes a selected number of members of the population. The number of respondents involved in this study were 10 respondents from a population, namely students in the Department of Building Engineering Education of IKIP Gunungsitoli.

The method of data collection was done by using a questionnaire method, which is distributing questionnaires to students via Google form. Measurement of the results of the questionnaire was carried out using a Likert scale which was divided into a scale of 1 to 4 , namely Strongly Disagree (STS), Disagree (TS), Agree (S) and Strongly Agree (ST) with the scores of each scale in table 1 below:

Table 1. Scale values

\begin{tabular}{lccll}
\hline Pertanyaan & STS & TS & S & SS \\
\hline Nilai & 1 & 2 & 3 & 4 \\
\hline
\end{tabular}

This research follows the steps that will be taken to achieve the desired goals, which are as shown in Figure 1 below:

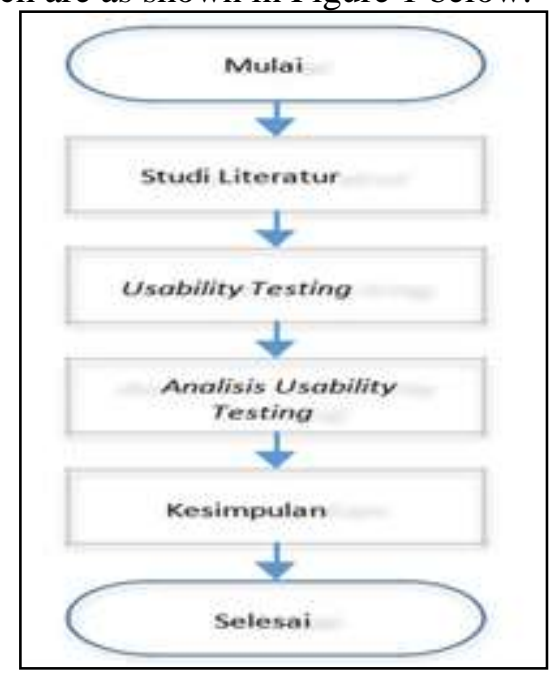

Figure 1. Research Flow

Information :

Literature Study: Search for references on google classrooms, usability and Likert scale

Usability testing: distributing questionnaires to respondents 
Usability testing analysis: Recording the results of filling out the questionnaire and calculating the usability value

Conclusion: Drawing conclusions from the usability value

\section{Result and Discussion}

The first step in usability testing was arranged questions that will be used for questionnaires and distributed to respondents who have been selected in a population within the scope of the Deparment of Building Engineering Education, IKIP Gunungsitoli.

The questions in the questionnaire are 16 questions which are divided into 4 factors, namely usefulness, satisfaction, ease of use, and ease of learning.

After distributing the 16 questions in the questionnaire to 20 respondents, then a recap was carried out on the results of the questionnaire. The assessment was carried out using a Likert scale with a scale of 1 to 4, namely STS (1), TS (2), S (3), and SS (4). The results of the recapitulation can be seen in Table 2 below:

Tabel 2. The results of the assessment recap

\begin{tabular}{|c|c|c|c|c|}
\hline $\begin{array}{l}\text { Fak } \\
\text { tor }\end{array}$ & $\begin{array}{l}\mathbf{N} \\
\mathbf{o}\end{array}$ & Pertanyaan & $\begin{array}{c}\text { Peni } \\
\text { laia } \\
\text { n }\end{array}$ & $\begin{array}{c}\text { Rata- } \\
\text { rata } \\
\text { Penila } \\
\text { ian } \\
\text { Tiap } \\
\text { Fakto } \\
\text { r }\end{array}$ \\
\hline \multirow{4}{*}{$\begin{array}{l}\text { Usef } \\
\text { ulne } \\
\text { ss }\end{array}$} & 1 & $\begin{array}{l}\text { Aplikasi ini } \\
\text { membantu anda } \\
\text { menjadi lebih efektif }\end{array}$ & 2,8 & \multirow{4}{*}{2,95} \\
\hline & 2 & $\begin{array}{l}\text { Aplikasi ini } \\
\text { membantu anda } \\
\text { menjadi lebih } \\
\text { produktif }\end{array}$ & 2,8 & \\
\hline & 3 & Aplikasi ini berguna & 3,1 & \\
\hline & 4 & $\begin{array}{l}\text { Aplikasi ini dapat } \\
\text { menghemat waktu } \\
\text { saat anda } \\
\text { menggunakannya }\end{array}$ & 3,1 & \\
\hline \multirow{5}{*}{$\begin{array}{l}\text { Ease } \\
\text { of } \\
\text { use }\end{array}$} & 5 & $\begin{array}{l}\text { Aplikasi ini mudah } \\
\text { digunakan }\end{array}$ & 3,25 & \multirow{5}{*}{3,15} \\
\hline & 6 & $\begin{array}{l}\text { Aplikasi ini sederhana } \\
\text { untuk digunakan? }\end{array}$ & 3,3 & \\
\hline & 7 & $\begin{array}{l}\text { Aplikasi ini user } \\
\text { friendly }\end{array}$ & 3,05 & \\
\hline & 8 & $\begin{array}{l}\text { Anda } \\
\text { menggunakannya } \\
\text { tanpa intruksi tertulis }\end{array}$ & 3 & \\
\hline & 9 & Anda dapat & 3,15 & \\
\hline
\end{tabular}

\begin{tabular}{|c|c|c|c|c|}
\hline & & $\begin{array}{l}\text { melakukannya } \\
\text { recovery dengan cepat } \\
\text { dan mudah ketika } \\
\text { membuat kesalahan }\end{array}$ & & \\
\hline \multirow{2}{*}{$\begin{array}{l}\text { Ease } \\
\text { of } \\
\text { lear } \\
\text { ning }\end{array}$} & 10 & $\begin{array}{l}\text { Anda mempelajari } \\
\text { penggunaanya dengan } \\
\text { cepat }\end{array}$ & 3,15 & \multirow{2}{*}{3,25} \\
\hline & 11 & $\begin{array}{l}\text { Anda mudah } \\
\text { mengingat bagaimana } \\
\text { cara menggunakannya }\end{array}$ & 3,35 & \\
\hline \multirow{5}{*}{$\begin{array}{l}\text { Satis } \\
\text { facti } \\
\text { on }\end{array}$} & 12 & $\begin{array}{l}\text { Anda puas dengan } \\
\text { aplikasi ini }\end{array}$ & 3,05 & \multirow{5}{*}{3,09} \\
\hline & 13 & $\begin{array}{l}\text { Aplikasi ini } \\
\text { menyenangkan untuk } \\
\text { digunakan }\end{array}$ & 3,2 & \\
\hline & 14 & $\begin{array}{l}\text { Cara kerja aplikasi ini } \\
\text { sudah seperti yang } \\
\text { anda inginkan }\end{array}$ & 3 & \\
\hline & 15 & Aplikasi ini luar biasa & 3,05 & \\
\hline & 16 & $\begin{array}{l}\text { Aplikasi ini nyaman } \\
\text { untuk digunakan }\end{array}$ & 3,15 & \\
\hline
\end{tabular}

The following is a Graph of Usability Measurement for the Google Classroom Application as E-learning in the Department of Building Engineering Education of IKIP Gunungsitoli based on the data in table 2.

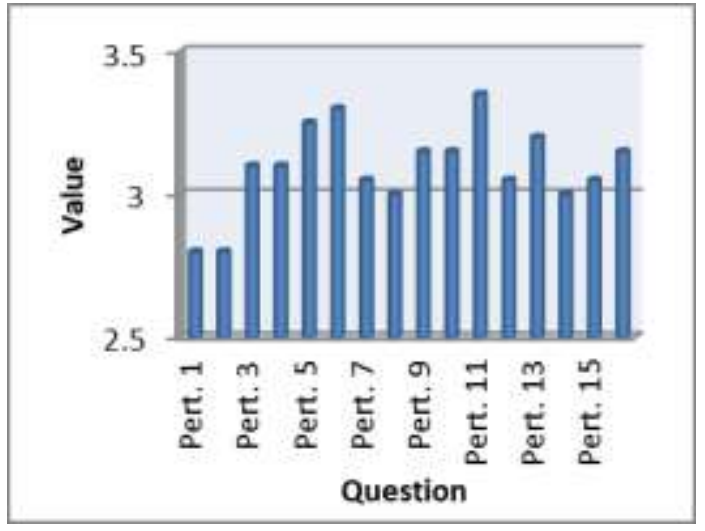

Figure 2. Graph of Usability Measurement of Google Classroom Application for E-learning in Department of Building Engineering Education of IKIP Gunungsitoli.

Table 2 shows the value of each factor contained in usefulness, ease of use, ease of learning, and satisfaction. For each factor, an average value for usefulness = 2.95; can be obtained; ease of use $=3.15$; ease of learning $=3.25$; and satisfaction $=$ 3.09 .

If adjusted for each factor, it can be said that the Google Classroom application used by students in The Department of Building Engineering Education of IKIP Gunungsitoli as e-learning has a good value. 
From the results of this value each factor can be interpreted as follows:

1. The usefulness factor value is 2.95 which indicates that the Google Classroom application has had a bad use, meaning that this application is not appropriate if used as e-learning.

2. The value of the ease of use factor is 3.15 which indicates that the Google Classroom application has good ease of use, meaning that this application has no difficulties in the process of using it.

3. The value of the ease of learning factor is 3.25 which indicates that the Google Classroom application has a lack of ease in learning, meaning that this application has no difficulty in the learning process to use it.

4. The satisfaction factor value is 3.09 which indicates that the Google Calssroom application has good satisfaction, meaning that this application is satisfactory in its use as elearning. This is also influenced by the ease of use factor and good ease of learning which causes the satisfaction score to be good.

\section{Conclusion}

The recap results of usability assessments on the ease of use, ease of learning, and satisfaction factors show a good value, while the usefulness factor shows a less good value. This is because the use of the Google Classroom application is not quite useful for several courses, especially in the Building Engineering Education study program. So if the usability factor is not good, then the use of the Google Classroom application must be adjusted to the courses that can be supported by Google Classroom.

\section{References}

A. Lund. [Online]. Available: https://www.researchgate.net/publicati on/230786746_Measuring_Usability_ with_the_USE_Question naire.
D. R. Rahadi, "Pengukuran Usability Sistem Menggunakan Use Questionnaire Pada Aplikasi Android," Jurnal Sistem Informasi (JSI), vol. VI, no. 1, pp. 661-667, 2014.

J. Rubin dan C. Dana, Handbook of Usability Testing, Second Edition: How to Plan, Design, and Conduct Effective Test, Indianapolis: Wiley Publishing, 2008.

Kuntarto Eko. 2017. Keefektifan Model Pembelajaran Daring Dalam Perkuliahan Bahasa Indonesia Di Perguruan Tinggi. Journal Indonesian Language Education and Literature. Volume 3, No 1, 99-110

Mustofa Mokhamad, dkk.2019. Formulasi Model Perkuliahan Daring Sebagai Upaya Menekan Disparitas Kualitas Perguruan Tinggi. Walisongo Journal of Information Technology. Volume 1, No 2, 151-160.

S. Guritno, Sudaryono dan U. Rahardja, Theory and Application of IT Research, Yogyakarta: Andi, 2011.

S. Iftakhar, "Google Classroom: What Works and How?," Journal of Education and Social Science, vol. III, pp. 12-18, 2016.

W. Handiwidjojo dan E. Lussy, "Pengukuran Tingkat Ketergunaan (Usability) Sistem Informasi Keuangan Studi Kasus: Duta Wacana Internal Transaction (Duwit)," JUISI, vol. II, no. 1, pp. 49-55, 2016. 